\title{
FESTIVE AND DAILY INTERACTION BETWEEN NEIGHBOURS IN CONTEMPORARY LITHUANIA AND BULGARIA
}

\section{Rasa Paukštyte்-Šaknienè}

Senior Researcher at the Department of Ethnology and Anthropology, Lithuanian Institute of History, Lithuania

e-mail:rasa.sakniene@gmail.com

\begin{abstract}
The article is based on data from ethnographic field research that was conducted in Vilnius and the Vilnius are in 2017-2020 and in Sofia in 2019. To meet the aims of this research comparing interactions between neighbours in the cities of Sofia and Vilnius respectively, I analysed two types of neighbourhood: the formal, which is determined by territorial proximity and the necessity of mutual assistance; and the informal, which is based on friendly feelings and the desire to spend leisure time and celebrate together. However, the specific features of field research in these cities highlighted another aspect of the neighbourhood, namely, how it functions in public and private spaces. A majority of respondents associated friendship with visiting one another at home, while birthdays were the most common celebration for spending time together. Older respondents, mostly those who were from villages, remember how neighbours would interact in the village environment and how they brought this concept of neighbourhood to the city, naturally comparing it with the situation there and pointing out generational differences. However, in the opinion of the majority, the city environment changed the nature of interactions between neighbours and
\end{abstract}


created a unique concept of neighbourhood that was based on close social links, which sometimes developed into friendship.

Keywords: neighbourhood, Vilnius, Sofia, mutual assistance, leisure, festivals, village, city

\section{Introduction}

The concept of the neighbourhood is a very broad idea applied in many academic disciplines. From the ethnological perspective, the concept of neighbourhood is balanced somewhere between being a geographical concept and a value-based category. As the German ethnologist Klaus Roth noted, even though the neighbourhood is a social-spatial category, this concept can also encompass both close and more distant neighbours, depending on one's choice (Roth 2001: 9-34). Neighbourhood studies have shown that interactions between neighbours can be very different. My own research, conducted in 2017-2018 in settlements of varying sizes (villages, towns and cities) in locations relatively close to the Lithuanian capital Vilnius, allowed me to distinguish two types of neighbourhood, one distant and formal, the close and informal. The first was determined by territorial proximity, while the second was associated not only with territory and the necessity of mutual assistance, but also with a group of people who felt a connection through friendly emotions, and who could choose freely, without any feeling of obligation, how to spend their leisure time or to celebrate various occasions. Research with two age groups, one older (born before 1969), the other younger (born after 1969), revealed that it was the older generation who noticed the main changes that had taken place during the last few decades. The weakening of social relations between neighbours was influenced by the age of the respondents, the turnover of neighbours and rapid processes of modernization that allowed people to remain independent of those who lived nearby. It was found that, over time, the weakening of good neighbourly relations is detrimental to close neighbourhoods (Paukštytė-Šaknienè 2018: 35-61; 2020: 51-64). The study of neighbourhoods in settlements of varying sizes also showed that there were weaker social relations in one village (Neméžis) which bordered the Lithuanian capital of Vilnius (part of the settlement had already been incorporated into the city), compared to other settlements that had been studied. Meanwhile, the Bulgarian researcher Meglena Zlatkova, who studied the phenomenon of the neighbourhood in a major city in her country, Plovdiv, drew attention to the very rapid urbanization in Bulgaria during the socialist 
period, where migrants coming to the city from villages brought their ideas and habits of contact with neighbours (Zlatkova 2001: 185-192). This raised the issue of how neighbourhood links can be developed in a large city, where the extent of social assistance provided by one's neighbours is relatively smaller than in a village or town, while the neighbourhood is more strongly defined by territorial proximity. However, we should not yet dismiss the potential of the concept of a neighbourhood being brought by migrants from villages and towns into the city.

The aim of this article is to analyse neighbourhood connections based on the experiences of people living in Sofia and Vilnius. The analysis rests on ethnographic field research conducted in Vilnius and the Vilnius area in 2017-2020 as part of the Lithuanian Institute of History's project 'Leisure Time, Celebrations and Rituals in the Vilnius Region: Social and Cultural Aspects', and in 2019 in Sofia as part of the project 'Festive and Daily Culture in Bulgaria and Lithuania: Tradition and Modernity'. During these research projects, analogous questions were posed to respondents in semi-structured interviews conducted in both Lithuania and Bulgaria. Respondents were asked how they perceived their neighbourhoods, whether their understanding of them changed over time, and if so how. They were also asked how many neighbours they interacted with and whether they saw any differences between being neighbours and being friends. Moreover, they were asked how neighbours communicated and interacted, what forms of mutual assistance there were, and about the presence or absence of rewards for providing this assistance. The interviews ended with questions about joint activities among neighbours - leisure time and celebrations. The interviews were conducted with respondents of various ages, both genders, levels of education, different religions and nationalities. Respondents were interviewed in the yards of their homes, in parks or in other public spaces. In Sofia, the questions were asked in English and Russian, and in Vilnius in Lithuanian.

\section{Neighbourhood research}

Neighbourhood research in the city using the approach adopted in the present article has hardly been conducted in either Lithuania or Bulgaria. In the late nineteenth and first half of the twentieth century, research by Lithuanian ethnologists focused almost exclusively on village locations, and much less commonly on towns. According to Angelè Vyšniauskaitè, who studied com- 
munity customs, neighbourly relations were based on traditions that had been established in feudal times, which, despite changing somewhat in eastern and south-eastern Lithuania, basically remained the same until the mid-twentieth century. Interaction between peasants in the old patriarchal village was expressed through common work bees, collective involvement in communal village affairs, the provision of mutual assistance in various cases and the participation of all neighbours in the celebration of family and calendrical celebrations (Vyšniauskaitė 1964: 527).

The pioneer of systematic neighbourhood research in Lithuania was Antanas Mažiulis, who dedicated quite a lot of attention to the description of neighbourhood traditions in villages in Lithuania’s north-east (Mažiulis 1940: 246; Mažiulis 1941:91-96). However, this ethnologist's greatest contribution to neighbourhood historiography was the distinction between 'close' and 'greater' neighbourhoods. In his opinion, 'closeness' was a matter of two or three of one's closest neighbours maintaining a particularly close connection. The 'greater' category encompassed a small village or part of a larger village and was not close in most cases, but evinced rather a kind of neighbourliness 'based more on necessity rather than sincerity' (Mažiulis 1957: 244).

As lifestyles changed in the second half of the twentieth century and the way services were provided changed, many of the forms of unrewarded assistance naturally disappeared from village communities. It was no longer neighbours who helped out with most of the communal work on the farmstead, but relatives coming from the cities. They planted vegetable gardens, harvested the potatoes, collected hay, picked berries and fruit, and received some of this harvest in kind, as well as various products and food and drink during the work (Merkiene 2002: 100). This was in large part due to the start of geographical and social mobility in the second half of the twentieth century, as well as less experience among the older generations, while the demise of the community's authority and responsibility for the behaviour of its members shattered the neighbourly communal traditions that had been dominant in Lithuanian villages up to the mid-twentieth century (Bylaitè-Žakaitienè 2012: 282). Some of the communal customs that had been maintained among neighbours were analysed in the early 21st century. For example, the traditional custom of visiting new-born children in Dzūkija still existed just a few years ago, a custom which, according to respondents, was intended to foster closer friendships between families and was even 'a good opportunity to heal arguments and disagreements between 
neighbours' (Paukštytė-Šaknienè 2002: 80). A separate study was dedicated to comparing the forms of neighbourly relations in one town and one village. It was found that communication between neighbours living near one another in villages in the second half of the twentieth century was more active than that between neighbours living in cities (Udraite 2016: 920-922). However, there have been no comprehensive ethnological studies on the city in the early 21 st century. We must therefore rely on sociologists who state that, in recent years, urban communities have come to be characterized by social alienation and greater social mobility, leading to a drop in community feeling. Links in these communities are more likely to be based on specialized relations, rather than on providing assistance: that is, members of urban communities use different types of links in order to acquire particular resources. In the city, individuals are not included in traditional and close communities, but they constantly manoeuvre between sparse networks that are spread out over a given space and that are often changing. City communities are not neighbourhood communities, but are more like dispersed networks that perform the functions of support and socialization (Leliūgienè and Sadauskas 2011: 1293). My research in Vilnius showed that in this city, communities of neighbours had formed that were based on families living in close proximity to one another spending time together on a regular basis.

Zlatkova's works stand out from those of other researchers in Bulgaria. Based on research conducted in the post-socialist city of Plovdiv in Bulgaria, the second largest city in the country, she discussed how urban spaces were defined from the viewpoint of the people based on their everyday life activities, and how the latter were associated with redefining and giving new meaning to traditional forms of social interaction and models of behaviour (Zlatkova 2001: 185-92). In a later article, she discussed the ways in which public and private space was divided, analysing the practices for settling down in communal spaces in daily life and showing how they can be made one's own (Zlatkova 2015: 41-60). Of research conducted in neighbouring countries, it is worth mentioning a study published in 2019 by Polish sociologists working in three cities of different sizes (Warsaw, Poznan and Wronki), where the importance of the proper functioning of spatial neighbourhoods was also a prime focus. The second most important factor, however, was highly social in nature and related to firmly embedded social rooting in one's place of residence, which created the social premises for building long-term relationships and a common 
platform of lifestyle and interests where spatial anchoring plays a less significant role (Nowak et al. 2019: 70-1).

Zlatkova's research on the socialist period in Bulgaria, as in many other post-socialist countries, may be described as concerning the forced urbanization and modernization that were introduced after World War II. This is why a large number of village residents moved to the cities and found employment in the industrial sector, though this migration also provoked a housing shortage (Zlatkova 2015: 45). An analogous migration from villages in the postWorld War II period that radically altered the composition of the population in Vilnius and other cities was also noticed in Lithuania (Kasparavičienè and Trinkūnienè 1995: 7-46). However, it must be stressed that the ethnic composition of residents in Vilnius and Sofia is different. In Sofia, Bulgarians make up as much as 96 percent of the total population, with the Roma making up just 2 percent, and Turks 1 percent (data from 2011). Vilnius, on the other hand, is a poly-ethnic city, where (data from 2011) Lithuanians made up only 63.2 percent, Poles 16.5 and Russians 11.9 percent.

Ethnographic field research conducted in Sofia and Vilnius in recent years showed that the formation of the neighbourhood concept and the stability of the links between neighbours in today's society was greatly influenced by one's place of residence, type of housing (apartment building or a private home), time spent living in the same place, changes of residence and the person's age. However, other circumstances were just as important, such as personal interests, education, one's preferred lifestyle, family status, the features of a person's character, etc. According to the research conducted in Sofia, a majority of the respondents who lived in apartments (sixteen live in apartment buildings, five live in privately owned homes) had lived in the same building for over a decade (thirty to forty years). A similar situation was found to exist in Vilnius (sixteen live in apartment buildings, three live in privately owned homes). Living nearby, in the respondent's geographical location, unavoidably determined certain contacts, such as living in an apartment building, when there are some things in common between all the residents, such as a shared roof and water supply system. Private home-owners also share connections in the form of common obligations. On the one hand, in both Vilnius and Sofia, as in Lithuania's villages and towns, neighbours share a bond due to mutual assistance. People usually look to their neighbours when they need to borrow something, to ask them to keep an eye on their apartment while they're away, to mind the children, and 
so on. Neighbours provide necessary assistance in the event of illnesses as well. In this sphere, we are unlikely to find any fundamental differences between Vilnius and Sofia. In this paper I shall accordingly concentrate on the 'close' neighbourhood, which encompasses daily and festive occasions where time is spent together, as well as the spaces where this interaction occurs.

\section{Interaction between neighbours in the public space: 'what goes on outside the door of the apartment'}

Zlatkova mentioned the importance of communal spaces in post-socialist cities in Bulgaria. However, they not only provide an opportunity to receive social assistance when dealing with health or household issues, but also encourage daily friendly interactions. According to Zlatkova, 'Residential areas are both physical and social constructions, each one of them has its own images and places of memory, each can be a site of the collective memory of a community, a family or of all urban residents. Thus, a residential area is a living space, a spatial and human entity, a togetherness of collective life, a framework of meanings created by its citizens' (Zlatkova 2015: 44).

This is also evident from my own field research in Bulgaria and Lithuania. One of the most important places where neighbours meet and spend time together is the communal yard, where there are recreational spaces, like benches and children's playgrounds. Benches are also found near apartment building stairwells, where people, especially the older generation, spend a lot of time communicating with one another, as well as with other neighbours who were coming and going, or simply watching the nearby surroundings. This is like a closed space which is treated as their own by the residents who share the communal yard, as others rarely pass by. This situation was very evident during the research in Sofia: going from one apartment building yard to another searching for respondents, we were immediately take for strangers. Soon enough, we received an explanation: neighbours appeared to recognise the regulars from not just their own apartment buildings, but those nearby as well. Analogous observations were noticed when walking through apartment building yards in Vilnius too. Even though at first glance the yards in Vilnius and Sofia might appear to be alike, they do have particular characteristics specific just to each yard. For example, in yards in Sofia there are recreation zones (benches, playgrounds), though we often also noticed a random, non-standard pergola, or a table or bench. It turns out that these had been made by some of the local 
inhabitants, with the agreement of their neighbours. That is why these fixtures are not just considered common property, but also as a communal space for interaction. Yet as the field research showed, it is usually groups of people who were just connected because they were formally neighbours who gathered in these spaces, as well as those who had common interests determined by common hobbies, or were of the same age or gender. Understandably, over the course of time these groups may regroup themselves differently, yet as the research showed, probably the most stable factor helping to maintain ties was a similar age and the similar time of initially having moved into the building.

It also became apparent that the space in the yard chosen for interaction may differ. For example, while the older women might assemble on benches right near their stairwell, younger women with small children would gather at the playground, or even another neighbouring yard. When observing this interaction between neighbours, it became clear that groups of neighbours had not only formed on the basis of specific characteristics, but that there was also an established time when they would gather in this space - mothers with children and older men and women would each come out at a specific time. There were often cases of mixed groups interacting, but there were also activities that were clearly distinguished by gender. Another location for interaction between neighbours was the public parks that have grown up surrounded by apartment buildings, which is quite typical of Sofia. The neighbours from one, a few or several stairwells (buildings) would go there for a walk. Neighbours taking their pets for a walk also choose their own particular spaces.

A similar situation was observed in Vilnius, in the yards of apartment buildings: older women would be chatting in groups sitting on benches, and mothers with children would also gather, but less commonly men. In the evenings, their places would often be taken over by youths. The long-term observation of these yards nestled among the apartment buildings in my vicinity led me to notice that neighbours go for walks or sit down in spaces further away from their own buildings as well, going along specially made walking paths, in the forest, etc. Due to the quarantine, some of the interviews were conducted via telephone, so observation could not take place in other suburbs of Vilnius. A slightly different situation has become established in the surroundings of private homes (usually those that are relatively recent), where spaces have been especially installed at the initiative of neighbours themselves for purposes of interaction. The survey of respondents supported these observation-based insights. 
For one resident of Sofia who had been born in 1935, the most important thing was good company, in the form of the same group gathering at the same place. She spends a lot of time with female neighbours of a similar age, sitting on a bench near their building. Even though a majority of the residents in the building are now from a younger age group, they always say hello to her when going past, asking her how she is doing, which was important for her, said the respondent. In this way, she maintains good neighbourly relations not just with her closest three female neighbours, but also with all the residents in the building. Daily interaction with neighbours in the communal space is characteristic of both men and women. As a Turk (b. 1960) who has been living in the same building for twenty years explained, at $6 \mathrm{pm}$, men and women who live in the apartment building will gather in the yard to sit on the benches and chat about politics, and common and personal matters. By communing every day, the neighbours share books, newspapers and various information. According to a woman born in 1939, the neighbours in her building also enjoyed gathering nearby in the evenings: the men would gather in the late afternoon to play cards, while several female neighbours had a tradition of meeting at 10 o'clock and going to a cafe together. Now the men no longer gather due to older age and health problems, while the women who still can do so continue going out to the cafe. In the respondent's opinion, this type of habit of interaction did not occur with more recent neighbours, due in part to their different ages. As a respondent born in 1939 said, each day, especially when the weather was fine, four or five female neighbours would gather in the yard at 10 oclock and would all go to the nearby cafe for some coffee and cake and a chat. However, in winter (or when the weather was not so good) or if one of them was ill, they would gather at one of their homes. According to her, the neighbourhood is critically important to pensioners, even if they have children and grandchildren with whom they often keep in touch by phone. Regular neighbourly interaction for someone who is no longer working and can rarely travel far from their own home was very important. One respondent born in 1956 said that, despite living in a private home, she still upheld the ritual of meeting several neighbours on Saturdays or Sundays to go to a cafe together. However, lately they have been gathering at the home of one of the women from the group rather than going to the cafe. This tradition of daily interaction, as the survey showed, has been maintained for many years by respondents from both apartment buildings and private homes. However, the coffee-drinking ritual has been maintained mostly 
by the older women. Younger women did not really have this kind of ritual, yet they did notice that the older generation did interact regularly in the yards.

It should be noted that the younger residents of Sofia (mostly those who were single) did not have any stronger bonds with their neighbours. One Bulgarian respondent born in 1983 who had lived in the same apartment building since her birth stated that to her neighbourhood was being able to 'borrow or loan something, carry something, wake up or look after each other's kids. Even if they run into one another by chance, even if it is every day, they always stop and chat'. When asked what they talked about, she said it was mostly daily, household topics, but not about anything personal. Mothers taking their children out to play in the yard or city park would talk to their neighbours every day. One respondent born in 1983 observed that she saw how neighbours gathered in the yards according to their age and interests: old with old, mothers and kids with other mothers and kids, but she had no children of her own. A Bulgarian woman born in 1969 also noticed that, for a close-knit neighbourhood to form, the age, education, profession and interests of the neighbours was very important. Without finding anything in common, each neighbour ended up living in their own world. That is why, in many cases, family, relatives and friends became closer than neighbours, but if some common interests were shared with a neighbour, their bond could become very close, even friendly. The respondent also took the different time period into account: whereas earlier neighbourly relations were closer and whole families interacted, nowadays this is much less widespread.

Similar trends in neighbourly relations were observed in Vilnius. A male resident of Vilnius born in 1978 described neighbourhood as 'forced' social relations with people 'forcibly' living nearby. But although this was not a person's own, free choice, a bond would develop with one's neighbours, singling out a specific space uniting them, and leading to the formation of a unifying culture of interaction. The respondent who shared this experience had changed his place of residence numerous times in his life. As the man explained, he currently lives in a suburb of private homes where the members of their neighbours' association had reached an agreement to jointly purchase a plot of land which they used for communal, general purposes - gatherings, celebrations, outdoor games and the like. Common rules applied to all the neighbours. Among this group of neighbours there were various nationalities, different levels of education and different ages, but according to the respondent they all 
got along well together. Daily interaction was forming, as was handling common practical matters, creating certain traditions for celebrations, and so on. Yet the respondent added that he personally maintained closer ties with seven families (the neighbours' association consisted of around thirty families). It so happened that these were neighbours who lived in the closest proximity to the respondent, yet this closeness would probably not have formed had they not shared common interests, i.e., the things that encourage interaction not just out of obligation on account of living near one another, but things that also satisfy a person's personal needs.

According to a man born in 1965, neighbours are linked by friendly interaction, as when the adults and children all get along well together. His family lives in a suburb of private semi-detached houses, and this kind of interaction has grown up between five families. Even closer (in a way, forced) interaction can be observed between neighbours living in apartment buildings. A woman born in 1983 has lived in this type of residence (an apartment building) for only a year so far, and is close to only two families. However, all the residents in the building are linked by having the same roof and by the renovation work that goes along with it. In this way, all the neighbours are drawn into interaction, gathering in the yard or stairwell to discuss matters that relate to all of them, as in the view of this woman, neighbourhood is what goes on 'outside of the apartment's door', i.e., not in the private space of one's apartment.

A Russian resident of Vilnius born in 1976 agreed. For him, 'neighbourhood is a connection with certain people, in a certain territory'. He lives in an apartment building, helps his neighbours when needed and has a say in solving joint issues relating to the building. When neighbours run into one another, they stop to chat briefly about the weather or politics, but they don't actually visit one another in their homes. A Lithuanian resident of Vilnius born in 1985 found a more practical than emotional meaning of neighbourhood. According to this respondent, neighbours need to get along because this ensures a safe neighbourhood - household assistance, keeping an eye on each other's apartments, etc. A slightly different impression was shared by a woman living in a two-storey building. She has access to a communal yard that they share with the elderly neighbours who live on the first floor, where a lot of time is spent. When the yard needed to be fixed up, they initiated the work and contributed their own funds, thinking that it would be difficult financially for the elderly residents who lived off their pensions. However, later on the neighbours from 
the first floor offered to contribute, giving what they could. They acted similarly when the roof needed to be renovated. At first glance it would appear that this was related to things that fell under the category of joint ownership, however the respondent provided more examples of this kind of closer mutual interaction (when the older people look after the children, if need be, visit one another, etc.). This indicates that this interaction between the two neighbouring families was not formal: they were linked by the desire to help one another and to spend time in a common space.

Bulgarians and Lithuanians both drew attention to the different times we are living in. Their experiences revealed the changing nature of interaction between neighbours not only of different generations, but also in terms of the differences between city and village. A woman from Vilnius born in 1963 said that even though all her neighbours who lived in Fabijoniškès (a suburb of Vilniaus) were friendly (mostly Russians lived in her building), she felt there was a greater sense of community when compared to the times when she lived with her parents in Lazdynai (another suburb of Vilnius). Perhaps this was because most of the residents at that time had migrated from the villages and had not yet forgotten old traditions. It was common for older women to sit and chat on the benches near the apartment building stairwells, sometimes looking after the neighbours' children playing in the communal yard. Of course, there were neighbours who were closer, and others who were more distant in terms of interaction, but in the communal yard everyone felt a connection when there was some general work to be done, or when matters that affected everyone needed to be discussed. Nowadays, in the respondent's opinion, people have become much more closed, life-styles have changed, and the older traditions of neighbourly interaction have been forgotten. Now there is a heightened sense of insecurity in communal spaces: earlier, children could play by themselves in the yards because everyone knew each other's children. These days, children are rarely allowed to go outside in the yard by themselves and need supervision from adults. This claim is confirmed by the accounts of another two elderly women. According to one respondent who was born in 1940, during the Soviet period a lot of young people settled in Vilnius from the villages, initially to study, and ended up staying. That is why there was a greater sense of community among the neighbours, more sincere interactions based on the traditions they had brought from the villages. For example, neighbours helped out in the event of a funeral or on other occasions without even being 
asked. This woman has lived in this particular apartment building since 1981 - a lot of people of a similar age and social class all moved in at the same time. Most had children, and through them the parents would also get to know one another. Interaction between these parents (now only two women from that group remain) exists to this day. Even though the neighbours in the apartment building are constantly changing, in recent times she has noticed more young people among her new neighbours. People greet one another and stop to chat in the stairwell, but that is as far as the interaction goes. The woman says she doesn't want to 'intrude too much' because she is already older and the two groups have different interests. A Russian woman born in 1955 shared similar experiences. She had been living in the same apartment building since 1972: the majority of the new settlers were people who had arrived in the city from villages, with closer interaction occurring both on a daily basis and during celebrations. Now she notices a greater sense of individualism in the current generation and their new forms of interaction and communication.

The tradition I observed during my fieldwork in Sofia, where a certain group of female neighbours would regularly go the local café, was not noticed in Vilnius, though women would often drop in on one another for a coffee. These gatherings did not occur at a fixed time, as was the case in Bulgaria, and they happened in the territory where the neighbours lived. For example, a resident of Vilnius born in 1976 said that she met with her neighbours to drink some tea in the communal yard, but that these gatherings were spontaneous, occurring when the idea popped into someone's head, or when there was a particular occasion. This woman would also regularly meet up with three other female neighbours on Thursdays to sing together. The respondent born in 1966 compared her experiences of living in apartment buildings in different locations (she had changed her place of residence a total of six times), saying that, even though she got along well with her neighbours at her current residence, relations with her neighbours at the previous residence were much closer. She was raising children at the time, and would thus often meet up with other mothers, helping one another, going over for a visit, drinking coffee and alike. According to another respondent, a woman born in 1974, she and her neighbours would meet on Saturdays in the communal space for a working bee, or to celebrate someone's birthday. A woman born in 1976 shared a ritual with her closest neighbour to invite one another over for tea once a week. According to a female respondent born in 1975 (who lives in an apartment building), working 
bees would always be followed by sharing and having food together, or one or another neighbour would cook shashlik on the barbeque, or they'd simply get together to chat or have a drink. Even though there was no regular schedule for these interactions, five or six families regularly interacted in this way.

Thus, in both cities, in some cases we would see neighbours looking after the communal building or providing social assistance, but communal spaces also formed in which one's leisure time could be spent. Respondents interviewed in Sofia spent relatively more time in public spaces. There was an established tradition of neighbours going to the local cafe on a daily basis, which was not observed in Vilnius. What both cities had in common was that in almost all cases the respondents identified a close neighbourhood with a certain number of neighbours with whom the relations being formed were closer than with other neighbours. A different type of interaction between neighbours depending on their generation was also observed

\section{Neighbourhood and friendship: 'the doors of the apartment are open to neighbours'}

In his analysis of neighbourhood in Bosnia, David Henig reminds us of the saying 'before starting to build a house, you need to find a neighbour.' He also uses the 'open door' metaphor, which is hardly conceivable in the city (Henig 2012: 3-19). This metaphor reminds us of the description of a close neighbourhood in a Lithuanian village given by Mažiulis, where one could borrow something from one's neighbour's house without even asking (Mažiulis 1957: 233-244). This demonstrates the trust, moral values and importance of private space needed in constructing a neighbourhood.

During my research in Sofia and Vilnius, it became clear that the contacts that had been established were often pursued not just in the public space, but also in the environment of one's private home. Thus, the question that naturally arises is whether living nearby determines friendly feelings (the concept of friendship in Vilnius and Sofia is discussed in an article by Ž. Šaknys (2018: 119-130). Respondents in Sofia were asked whether they had friends among their neighbours, and a majority said 'yes'. But could they describe the difference between neighbourhood and friendship? A frequent response was that the fundamental difference between a friend and a friend who was a neighbour was that personal things could only be discussed between friends. So, for neighbours 
also to become friends they had not only to share common interests: time was also needed during which this bond would be 'tested. The oldest of the respondents, a woman from Sofia born in 1933, said that she had been living in the apartment building for 55 years and that for her being neighbours with the women with whom she maintained closer relations was equal to friendship. These women had helped each other their whole lives, their families had spent time together and visited one another. According to this woman, even now, whenever her health and the weather was good, she would always go outside to sit on the bench near the building, where more of her friends would also gather. The elderly women would chat and treat each other to food and drinks. For example, on the day of our conversation, one neighbour sat by us and gave the respondent some of the cake (banitsa) she had just baked. A Turkish Muslim who had lived in Sofia for forty years and lived in the same building for twenty years said that for him, a 'good neighbour was better than a relative or colleague': he further said he had friends among his circle of neighbours.

Meanwhile, a Bulgarian woman born in 1983 who has been living in the same apartment building for 36 years said that she had close interactions with five or six neighbours, only three of whom she considered friends. According to the woman, it was only the neighbourly friends who could call each other up at any time, go to a cafe together, invite each other over for birthdays or sometimes even celebrate New Year's Eve together. Obviously not all the neighbours one is close to are necessarily considered friends as well. Based on personal experience, other opinions were also shared. A respondent born in 1956 said that, even though she got along well with her neighbours, they were not friends. The woman reasoned that people become friends only when they start being closer, sharing intimate details, which she avoided doing with her neighbours. In her opinion, open interaction could prompt rumours and discord among neighbours. According to another woman born in 1962, neighbours could be friends, but they also had to be of a similar age and have common interests. The fact that they lived near one another was not a condition for friendship, and she had no neighbours whom she would consider friends. A more radical approach to neighbours as friends was encountered among the younger respondents. A woman born in 1973 said that, even though her neighbours were pleasant, she didn't really interact with them or know them very well. This respondent had only lived in this building for a relatively short time, while time and a particular occasion were needed to establish a friendship. In the woman's view, friendship 
depended on common interests, ages and long years of knowing one another, which showed that the person could be trusted. Another woman born in the same year said that she only had a few close friends from her yard in her childhood with whom she played. At present, she did not have any friends among her neighbours. One had to trust the other person to become friends, while those sorts of relations had not formed with the current group of neighbours.

As the fieldwork with residents in Sofia showed, younger respondents would rarely consider the possibility of being friends with their neighbours. A resident of Sofia born in 1999 who lived in a private home said that there were many good neighbours living nearby. They would help one another, share cakes they had baked, etc., yet none would be considered friends. According to the respondent, 'my neighbours are not the people I would want to have closer relations with'. A respondent born in 1995 also said quite categorically that, even though she got along well with her neighbours, they were not her friends. Neighbours were people one would interact with on a daily basis, whereas friends involved more personal interaction. For example, on her birthday, she would only receive a gift or flowers from friends whom she had invited over to her place. The respondent born in 1995 did not celebrate such occasions with her neighbours, only with her friends. In her opinion, there was a difference between the concepts of 'neighbours' and 'friends'. She herself has one friend who was also a neighbour. She maintained good relations with the other neighbours, but would only talk to them about general things, go to the park together, and did not engage in the same type of interaction as she would with her friends. The way in which one interacts with one's neighbours also depends on the person's nature. For example, an English and Russian teacher born in 1988 said that for her, 'a place where people live is already a neighbourhood'. Neighbours might not always become friends, and even in cases of closer neighbourly relations (not friendship), people chose one another depending on their shared interests. You might want to go to a cafe with certain neighbours, less so with others. This woman said that, while she had no friends from among her neighbours, they did get on well and she liked everyone.

The research showed that, in present-day Vilnius, residents made a similar distinction between friends and neighbours. In the opinion of one resident of Vilnius born in 1946, neighbours had the potential to become friends, but their relations had to be very close. She has been friends with one neighbour for a long time already, if there's a special occasion she invites her over to her 
place, and they spend their leisure time together. According to a woman born in 1970, neighbours either become friends or remain simply neighbours. She was lucky, as she was on friendly terms with two neighbouring families. At first the children started playing together, then the parents started talking and interacting, finding they shared similar hobbies and interests. A similar situation developed for another respondent, where the friendship began with the children and then extended to the parents, who also became friends and ended up going on trips together, visiting each other at their rural properties, etc. A woman born in 1976 also said that neighbours can be friends, but not always. Forming a friendship requires a lot of time, shared memories and the like, which is more difficult to achieve with neighbours, as they can change. A woman from Vilnius born in 1966 shared her experiences of friendship with neighbours. She said that when she used to live in her earlier apartment, she had just had her children. It was through them that she became friends with neighbours of a similar age, who were also raising children. They had their daily rituals, e.g., going for daily walks with the children, having coffee together at the cafe or when their children were napping, at each other's places. They would always celebrate the children's and parents' birthdays together. At the time, it felt as if she had become very good friends with those neighbours. However, when their place of residence changed, initially they try to keep the friendship going, but over time this happened less and less frequently, and ultimately it came to a natural end.

The opposite situation was also observed: a woman born in 1940 said how a friendship that started through being neighbours with one particular family lasted right up until they passed away. Even though both families changed their places or residence, and moved to different cities, they always remained friends by writing letters, visiting one another, and celebrating birthdays together, as well as other occasions. Obviously, a spiritual closeness is required for this kind of friendship to last. Other respondents agreed. According to one woman born in 1966, if people become friends, they feel the desire to celebrate birthdays, New Year's Eve or even the second day of Christmas together, inviting each other over. When one woman born in 1976 settled down in Užupis (a suburb of Vilnius), her university friends became her neighbours, and their friendship has lasted up to now. However, in that time (she has lived in Užupis for over twenty years) she has made friends with other neighbours as well. The respondent was then raising three children, so it was through them that the 
parents also started interacting. Another female respondent born in $1962 \mathrm{had}$ an interesting case of friendship to share with us. Five other neighbours would constantly gather at one neighbour's place to celebrate her birthday, although the respondent did not interact very much with the other neighbours who gathered there. She was only close to two other neighbours, and only met the others when it was the birthday of the neighbours just mentioned. Among residents of Vilnius (born in 1976 and 1983), there are some who said that interaction between neighbours does not extend into the private space if that neighbour is not considered a friend. Nor was it very easy for older residents of Vilnius to make friends with their neighbours. As one woman who has been living in the same building for forty years said, she had a few female neighbours with whom she maintained closer interactions, but they never really became friends. Perhaps her interaction with others was affected because their viewpoints or interests did not always correspond, or because mutual trust did not develop. Another reason could be that the idea brought from her parents' home in the village - 'keep your neighbour at a polite distance, then you'll get along' - influenced the degree of her interaction with them.

Thus, the research showed that some neighbours can develop into friends, and that one of the features of that friendship was daily and festive interaction in both public and private spaces. Of all the respondents, it was young Bulgarians who stood out, some of whom indicated that they had no friends among their neighbours. However, people with young children established neighbourly relations that often developed into friendly relations more easily than other groups. An analogous situation was observed by researchers studying the neighbourhood in Polish cities (Nowak et al. 2019: 71).

\section{Celebrations with neighbours: a combination of public and private spaces}

For festive interaction in both Vilnius and in Sofia, neighbours usually come together on two main occasions -New Year and birthdays, or less commonly, on names days. According to a respondent from Sofia born in 1946, even though the main celebrations were Christmas and Easter, which Bulgarians usually celebrated with their families, they would sometimes invite one or other neighbouring family with whom they got along well at the time to celebrate a birthday or names day. A woman born in 1939 said that she celebrated not 
only her birthdays with her neighbours, but also New Year's Eve. However, this kind of close interaction had not yet formed with neighbours who had moved in more recently. These occasions were celebrated by respondents who lived in apartment buildings and those who lived in private houses. One respondent born in 1956 has lived in the same building for 53 years. Many of the same female neighbours still live nearby to this day, with whom she brings in the New Year either at one of their apartments, or in a restaurant they go to together. However, she only celebrates birthdays with one of these neighbours because both women happen to have the same birth date. Each one also invites their own circle of friends. According to a woman born in 1946, while she does not celebrate birthdays and other celebrations with her neighbours, they do gather outside in the yard to bring in the New Year, where they wish each other all the best. A unique custom among Bulgarians is to treat one's neighbours to food and drink before one's birthday. A woman born in 1962 explained how, on the eve of her birthday, one of her female neighbours would go over to her neighbour's place with some kind of treats. Then that neighbour, wanting to be polite, would give her a present the next day. I also happened to encounter this custom in the hotel where I was staying when one of the staff treated everyone to sweets, adding that she was doing so on the occasion of her birthday. This kind of custom has not been observed in Lithuania, where treats are offered only after someone has received birthday greetings or has received a gift.

In Bulgaria, unlike in Lithuania, festive gatherings among neighbours are more common among those from the older generation. However, the spectrum of occasions celebrated with neighbours is slightly broader than in Bulgaria, even though joint celebrations of New Year and birthdays predominates in both countries.

In Lithuania, according to a woman born in 1970, as for the majority of respondents, it has become common to celebrate children's birthdays together by inviting the neighbours' children over. Neighbours also gather to mark St John's Day (Midsummer) and New Year's Eve. They gather in the communal apartment building yard, and everyone brings food and drink to share. A Vilnius woman born in 1974 who lives in an apartment building also said she celebrated various occasions with several neighbours. New Year's Eve celebrations were particularly memorable - five families would get together. They would decide who would make particular dishes in advance and who would be the host. Their celebrations would usually start with dinner and be followed by games. One of 
the more interesting games was to throw dice to win a prize (these gifts would be purchased in advance by all the neighbours 'chipping in', and they would all be nicely wrapped so that no one could guess what was inside). At midnight everyone would go outside to watch the fireworks and then come back inside to continue celebrating, eating and drinking. The children would be put to bed at one of the neighbours' homes.

At Christmas (even though it is considered a family celebration), these neighbours would decorate the stairwell together and treat others to cookies that would be left in the stairwell. They also gathered together to celebrate St John's Day: the children would play, and the adults would also think up all sorts of activities. Sometimes neighbours would not necessarily celebrate together, but they would all try to create a festive atmosphere in a public space. As one woman from Vilnius who was born in 1984 explained, even though Christmas and Easter were family celebrations, neighbours would sometimes leave cake, decorated Easter eggs or tiny Christmas buns (kalèdaičiai) for one another on their doorsteps. A Polish woman who lives in Vilnius (b. 1955) also added that, even now, the women would decorate the stairwell ahead of celebrations, such as the New Year, Christmas and Easter. Neighbours would also come together to mark Shrovetide traditions. A Vilnius woman born in 1976 said that whoever wanted to celebrate Shrovetide would gather in the communal yard and visit neighbours who lived further away. A man born in 1978 said that a tradition had formed whereby Shrovetide was celebrated in their neighbourhood community: children would go from house to house dressed as traditional Lithuanian Shrovetide characters 'begging' for pancakes and sweets, and then gather in a communal space to set fire to the More straw-lady. Both neighbours who lived in apartment buildings and those who lived in semi-detached houses spoke about the communal celebration of Shrovetide. A male respondent born in 1965 said that his neighbours had been marking this occasion for six years already, yet the more important New Year's Eve would have neighbours gathering in the street, letting off fireworks, greeting one another, sometimes sharing treats or inviting one another over to their homes. Older respondents were also found to celebrate New Year's Eve with their neighbours more frequently. A woman from Vilnius who had been born in 1946 and who lived alone celebrated the New Year with her closest neighbours in 2019.

The research for this paper showed that celebrations brought neighbours together in the public and/or private home environment. Neighbouring fami- 
lies who maintained close and friendly relations with one another were often inclined to celebrate such occasions in their home environment. It was birthdays that most commonly brought neighbour-friends together in both cities. Even though neighbours in Vilnius were more likely to celebrate on more occasions and were marked in the public space, the participants in these celebrations were not necessarily identified as friends by the respondents.

\section{Conclusions}

To achieve the aims of this research of comparing interactions between neighbours in the cities of Sofia and Vilnius, in this I have analysed two types of neighbourhood: the formal, which is determined by territorial proximity and the necessity of mutual assistance; and the informal, based on friendly feelings and wanting to spend leisure time and celebrations together. However, the specific features of field research in the two cities highlighted another aspect of neighbourhood, namely, how it functions in the public and the private spaces. The research showed that in both Sofia and Vilnius, a communal public space would be chosen or sometimes even created to spend time together both on a daily basis and when marking celebrations, or in some cases, neighbours would interact in the private surroundings of their home. Three neighbourhood categories can be distinguished at this level: 1. those that are limited to just necessary mutual assistance; 2 . those that include incidental or pre-planned daily or festive interaction in a public space; and 3. those neighbourhoods that develop further into pre-planned daily and festive interaction in the private space. Often, the latter two groups overlap in response to the different ratios of neighbourly and friendly feelings that are shared.

In both Lithuania and in Bulgaria, neighbourhoods from the second category dominate, as public spaces are used to spend time together with neighbours on a daily basis and to mark certain celebrations. In Sofia, this is more typical of the older respondents, as the younger generation in Bulgaria has have less interaction with their neighbours than do younger people in Lithuania. In Vilnius, young neighbours often celebrate special occasions together, but a public space set aside for celebrations does not make them feel obliged to develop friendly relations. In both Vilnius and Sofia, it appears that having young children has a strong influence on the intensity of neighbourly relations and whether these will develop into friendship, as neighbours feel a bond in 
caring for children, sharing common experiences and later celebrating special occasions together. In both cities, some respondents did have friends among their neighbours, but they do not equate being neighbours with being friends, and they make a clear distinction between these concepts. Friendship is expressed by spending time together in public and private spaces. A majority of the respondents associated friendship with visiting one another at home, while birthdays were the most common celebration for spending time together. Older respondents, mostly those who came from villages, remember how neighbours would interact in the village environment. Having brought this concept of neighbourhood to the city, naturally they compared it to the situation there and pointed out generational differences. However, in the opinion of the majority, the city environment had altered interactions between neighbours and created a unique concept of neighbourhood that was based on close social links, some of which might develop into friendship.

\section{Notes}

${ }^{1}$ In Sofia in 2019 semi-structured interviews were conducted with 21 respondents born between 1933 and 1997. Almost all respondents were of Bulgarian nationality (there was one Turk and one Russian woman). Analogous research was conducted in 2020 and 2021 in the city of Vilnius during which 19 respondents who were born between 1934 and 1983 were interviewed (nationalities included Lithuanians, one Russian man and one Polish woman). Due to the quarantine in effect at the time, some of the respondents in Vilnius were interviewed over the phone

\section{References}

Bylaitė-Žakaitienè, Andželika 2012. Lietuvių etiketas ir bendravimo kultūra XX amžiuje [Lithuanian Etiquette and Communication Culture in the 20th Century]. Klaipèda: Klaipėdos universiteto leidykla.

Henig, David 2012. 'Knocking on my Neighbour's Door': On Metamorphoses of Sociality in Rural Bosnia. Critique of Anthropology, Vol. 32(1): 3-19.

Kasparavičienė, Vida, and Trinkūnienè, Inija 1995. Vilniaus gyventojų sudètis, tautiniai santykiai ir vertinimai [Composition of Vilnius population, ethnic relations and evaluations]. In: E. Krikauskienè (ed.) Vilniečio portretas: sociologiniai duomenys 
[Portrait of a Vilnius Resident: Sociological Data]. Vilnius: Filosofijos, sociologijos ir teisès institutas, pp. 7-46.

Leliūgienè, Irena; Sadauskas, Justinas 2011. Bendruomenès sampratos traktuotè ir tipologija [Approaches and Typology of The Concept of the Community]. Socialiniu mokslu studijos. Vol. 3(4): 1281-1297.

Mažiulis, Antanas 1940. Iš žmonių tarpusavio santykių [From Human Relationships]. Gimtasai kraštas [Native Land], Vol. 3-4: 242-246.

Mažiulis, Antanas 1941. Moterų tarpusavès papročiai [Women’s Mutual Customs]. Gimtasai kraštas [Native Land], Vol. 1-2: 91-96.

Mažiulis, Antanas 1957. Kaimynystė [Neighbourhood]. In: Lietuvių enciklopedija [Lithuanian Encyclopedia], Vol. 20. Boston: Lietuvių enciklopedijos leidykla, pp. 243-244.

Merkiené, Regina 2002. Tarpusavio pagalba ir issipareigojimai XX a. Lietuvos kaimo bendruomeneje [Mutual Assistance and Commitments in the 20th Century in the Lithuanian Rural Community]. Žemès ùkio mokslai 4 (priedas), pp. 93-103.

Nowak, Marek, Pluciński, Przemysław and Siatkowski, Andrzej 2019. Neighbourhood Circles: The Study of Urban Neighbourhood in Contemporary Poland and its Basic Outcomes. Człowiek i społeczeństwo, Vol. XLVIII: 55-73.

Paukštytė-Šaknienè, Rasa 2002. Lokalinès kultūros struktūrinès kaitos kontūrai: gimtuvių papročių ciklas XX a. Dzūkijoje [Countours of the structural Change in Local Culture: The Cycle of Birth Customs in the 20th Century Dzükija], Lietuvos etnologija: socialinès antropologijos ir etnologijos studijos, Vol. 2(11): 71-88.

Paukštytė-Šaknienė, Rasa 2018. Kaimynystès ryšiai šių dienų kultūroje: atvejis iš Vilniaus apylinkių [Neighbourly Ties in Contemporary Culture: Cases from the Vilnius Area]. Lietuvos etnologija: Socialines antropologijos ir etnologijos studijos, Vol. 18 (27): 35-61.

Paukštytė-Šaknienè, Rasa 2020. Neighbourhood and Sociocultural Values in the Lithuanian Ritual Year. The Yearbook of Balkan and Baltic Studies, Vol. 3 (1): 51-66. Guest editors Laurent Sébastien Fournier \& Irina Sedakova. https://doi. org/10.7592/YBBS3.03

Roth, Klaus 2001. Nachbarn und Nachbarschaftsbeziehungen in Europa als Forschungsproblem der Europäischen Ethnologie und der Interkulturellen Kommunikation, In: Roth, K. (ed.). Nachbarschaft: Interkulturelle Beziehungen zwischen Deutschen, Polen und Tschechen. Münster, New York, Munich, Berlin: Waxmann, pp. 9-34.

Šaknys, Žilvytis 2018. Friendship and Spending Time with Friends in the City in Lithuania and Bulgaria. The Yearbook of Balkan and Baltic Studies, Vol. 1: 119-130. 


\section{Rasa Paukštytė-Šaknienè}

Udraitė, Eglè 2016. Kupiškènų bendruomenė ir jos gyvenimas XX amžiuje [Kupiškis Community and its Functioning in the 20th Century]. In: A. Jonušytė (ed.). Kupiškis. Vilnius: Versmè, pp. 918-926.

Vyšniauskaitè, Angelè 1964. Kaimo buitis ir papročiai [Rural Life and Customs]. In: Vyšniauskaitè, A. (ed.) Lietuvių etnografijos bruožai [Lithuanian Ethnography]. Vilnius: Valstybinè politinès ir mokslinès literatūros leidykla, pp. 527-550.

Zlatkova, Meglena 2001. Changes in Urban Neighbourhoods in Present Day Bulgaria. Ethnologia Balkanica. Vol. 5, pp. 185-192.

Zlatkova, Meglena 2015. Gardening the City: Neighbourliness and Appropriation of Common Spaces in Bulgaria. Colloquia Humanistica, Vol. 4, pp. 41-60.

Rasa Paukštytè-Šaknienè, PhD, Senior Researcher at the Department of Ethnology and Anthropology, Lithuanian Institute of History, Vilnius, Lithuania. Her research interests are in the field of traditional and modern culture, family, neighbourhood, ethnic minorities, ethnology of city, the history of ethnology and festivity. She has field works in Lithuania, Byelorussia, Poland, Latvia and Bulgaria. 